\title{
MODELLING THE IMPACT OF A CULTIVATED OYSTER POPULATION ON THE NITROGEN DYNAMICS: THE THAU LAGOON CASE (FRANCE)
}

\author{
Cédric Bacher, Hélène Bioteau \& Annie Chapelle \\ IFREMER, rue de l'île d'Yeu, BP 1049, F-44037 Nantes Cedex, France
}

\begin{abstract}
The Thau lagoon (France) is an important site for the cultivation of Crassostrea gigas. The relationship between the oyster population and the environment was assessed through a model of trophic relationships. The results represent the initial step towards a more precise assessment of the biological fluxes in the lagoon. This preliminary model was based on the nitrogen dynamics among the following compartments: phytoplankton, zooplankton, oysters, detritus and dissolved inorganic nitrogen in the water column. Two other compartments were also considered in the sediment: detritus and dissolved nitrogen. The model considered the watershed input and seawater exchange between the lagoon and the open sea. The parameters were estimated from experiments on oyster ecophysiology, in situ primary production and biomass measurements, and by calibration of simulations against data series. The importance of vertical exchange of material between the water column and the sediment due to sedimentation, biodeposition by the cultivated oyster populations, and nutrient regeneration from the sediment, was supported by the model. Therefore, the model emphasized the impact resulting from oyster culture practices and the sediment contribution to nitrogen dynamics. Oysters could be considered as a nitrogen well that stabilizes the ecosystem by removing nitrogen over a longer time scale than zooplankton. Since grazing was dominated by the oyster compartment, zooplankton had a limited effect on phytoplankton dynamics. Moreover, model calculation demonstrated the critical role of detritus in oyster food ration. For instance, the sedimentation rate of particulate matter was doubled by the deposition by oysters. The model was sensitive to parameters controlling the primary production. For example, modifying these parameter values resulted in large winter accumulation of dissolved inorganic nitrogen, triggering a first phytoplankton bloom at the end of winter. This sensitivity stressed the importance of using experimental data for calibration of the model.
\end{abstract}

\section{INTRODUCTION}

During a NATO workshop entitled "Bivalve filter-feeders in estuarine and coastal ecosystem processes", the importance of the impact of filter-feeders on ecosystems has been shown (Dame 1993). The need for further research on interactions between the environment and filter-feeders, integrating field studies, mesocosm experiments and modelling approaches was also stressed. Previous studies have 
pointed out the ability of benthic populations to control and regulate the primary level of the foodweb (Officer et al. 1982; Herman \& Scholten 1990; Hily 1991). Intensive research was undertaken on the carrying capacity of the MarennesOléron Bay (France) in order to assess the relationship between nutrient input from rivers and the ocean and the growth of cultivated oysters (Héral 1993). Dame (1993) explained that one should consider the decline of natural oyster populations in the Chesapeake Bay when trying to explain the changes in the ecosytem dynamics. In this case, it was shown that the decline of the oysters due to overharvesting and diseases contributed to a lesser control of the phytoplankton by the filter-feeders.

Deslous-Paoli et al. (1993) raised the problem of sustainable oyster production in the semi-closed Thau lagoon (France), which is subject to dystrophic crises. A comprehensive research program was therefore set up to assess the role of cultivated Pacific oysters, Crassostrea gigas, in the Thau lagoon. Located on the French Mediterranean coast, this lagoon is an important site for oyster and mussel production, with a cultivated population of about 40,000 tons per year. It is a shallow lagoon with a mean depth of $4 \mathrm{~m}$; it is $19.5 \mathrm{~km}$ long and up to $5 \mathrm{~km}$ wide, with a total volume of $26510^{6} \mathrm{~m}^{3}$. The lagoon is almost closed, with a water residence time averaging 200 days. A simple model for the main nitrogen flows in the ecosystem is presented in this paper, which assesses the impact of oyster activity on the nitrogen cycle by modelling several major processes, including primary production, phytoplankton grazing by the cultivated oysters, and exchanges between sediment and water.

\section{MATERIAL AND METHODS}

Previous studies have focused on the spatial and temporal variability of the main variables: phytoplankton, zooplankton, nutrients, and bacteria in the water column (Legendre et al. 1989; Picot et al. 1990; Jouffre et al. 1991; Jarry et al. 1990). Large data sets with estimates of most variables are therefore available. Comparisons between phosphorus and nitrogen concentrations showed that nitrogen was the limiting factor (Hénard 1978). Consequently, only the nitrogen cycle was considered. The lagoon contains more nutrients than the external sea water. Watershed input was estimated, including small rivers, industrial, urban, and agricultural runoff (Gasc 1993). Hénard (1978) demonstrated the critical role of sediment in the nitrogen recycling by the mineralisation of the detritus. In summer, ammonium fluxes released from the sediment were larger (Picot et al. 1990) than ammonium excretion from the oyster population (Outin 1990).

Primary production ranged from $0.02 \mathrm{gN} / \mathrm{m}^{2} / \mathrm{d}$ in December to $0.28 \mathrm{gN} / \mathrm{m}^{2} / \mathrm{d}$ in July, similar to that of several other French Mediterranean lagoons (Vaulot \& Frisoni 1986). This production is 40 times greater than those in the nearby areas (Hénard 1978). The phytoplankton is dominated by diatoms, which comprise 


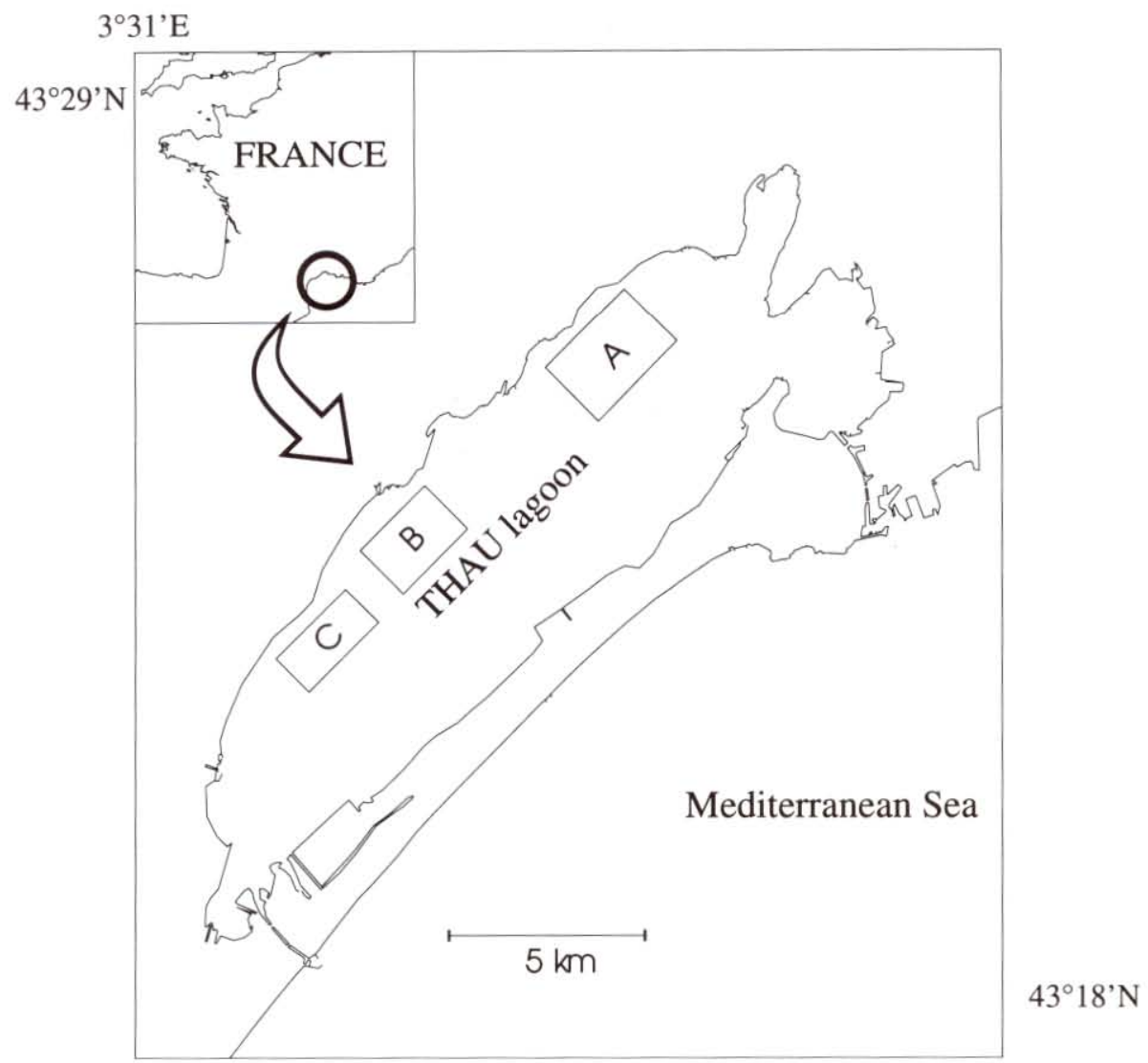

$3^{\circ} 44^{\prime} \mathrm{E}$

Fig. 1. Location of the Thau lagoon (France) on the Mediterranean coast. The oysters Crassostrea gigas are cultivated in the three areas $\mathrm{A}, \mathrm{B}$, and $\mathrm{C}$.

$70 \%$ of the total phytoplankton (Jarry et al. 1990). The spatial heterogeneity described by Jarry et al. (1990) has been related to the influence of external sea water, entering the north-eastern part of the lagoon. Moreover, zooplankton studies by Lam Hoai \& Amanieu (1989) showed a minimum abundance in winter (less than 2,000 individuals $/ \mathrm{m}^{3}$ ) and a maximum between May and September (from 10,000 to $20,000 \mathrm{ind} / \mathrm{m}^{3}$ ). Converted to nitrogen concentration, these abundances represent low values compared to the other variables (Bougis 1974). However, this compartment was kept in the model to assess the impact of nitrogen flow (e.g., on grazing, excretion, mortality), and to relate the zooplankton to other variables. 
Only little information is available regarding the mineral and organic particulate matter of the water column. Although strong correlations have been found in other systems (Héral et al. 1983), indirect turbidity measurements using a Secchi disk could not be linked to concentrations of particulate matter (Hénard 1978). There is likewise little information on the range of total and organic particulate matter (Outin 1990; Grenz 1989). Seawater turbidity was limited, with a Secchi depth ranging from $2.5 \mathrm{~m}$ to $7.7 \mathrm{~m}$, and particulate matter was less than $10 \mathrm{~g} / \mathrm{m}^{3}$. Although sediment resuspension by wind action on the water column was likely, no seasonal variation was observed and the relationship between turbidity and meteorological events was not significant. The nitrogen concentration of detritus was a significant factor in this ecosystem (mean value around $0.05 \mathrm{gN} / \mathrm{m}^{3}$ ).

Shellfish rearing areas occupied $20 \%$ of the whole lagoon acreage (Fig. 1). The stocking biomass was distributed among 3 areas (namely A, B, C) and reached 32,000 metric tons of oysters Crassostrea gigas (Hamon \& Tournier 1990). Since a single oyster (with a mean weight of $50 \mathrm{~g}$ ) filters about $4 \mathrm{l} / \mathrm{hr}$, the whole oyster population has a significant impact on the environment (Deslous-Paoli et al. 1992).

\section{MODEL ASSUMPTIONS}

The time scale of the system was related to the seasonal variables temperature and light driving the main processes. Since the time scale of the oyster growth is equal to one year, the oyster population integrated the smaller temporal fluctuations. Although the phytoplanktonic and zooplanktonic populations had faster kinetics (usually a few days), smoothing the short term variations of the environment is consistent. Disturbances resulting from the wind effect were ignored (Millet \& Cecchi 1992; Millet 1989). Therefore, the water column was systematically considered to be well mixed and homogeneous.

Since several of the parameter estimates used for the mathematical formulation of the processes were uncertain, the system was simplified through process hierarchisation. Moreover, the model was based on the following assumptions:

- the dissolved nitrogen was the limiting factor for primary production.

- although reaching $25 \%$ of the total amount of reared molluscs, the mussel population was excluded from the calculations.

Another hypothesis resulted from the lack of knowledge on culture practices, mainly the management of the oyster and mussel lines. In this model, only one oyster age class was considered, and the whole population was removed after one year:

- macrophytes, macroalgae and benthic consumers were excluded.

Five compartments were defined in the water column: phytoplankton, zooplankton, oysters, detritus and dissolved inorganic nitrogen. Two other compartments were also considered in the sediment: detritus and dissolved nitrogen. 


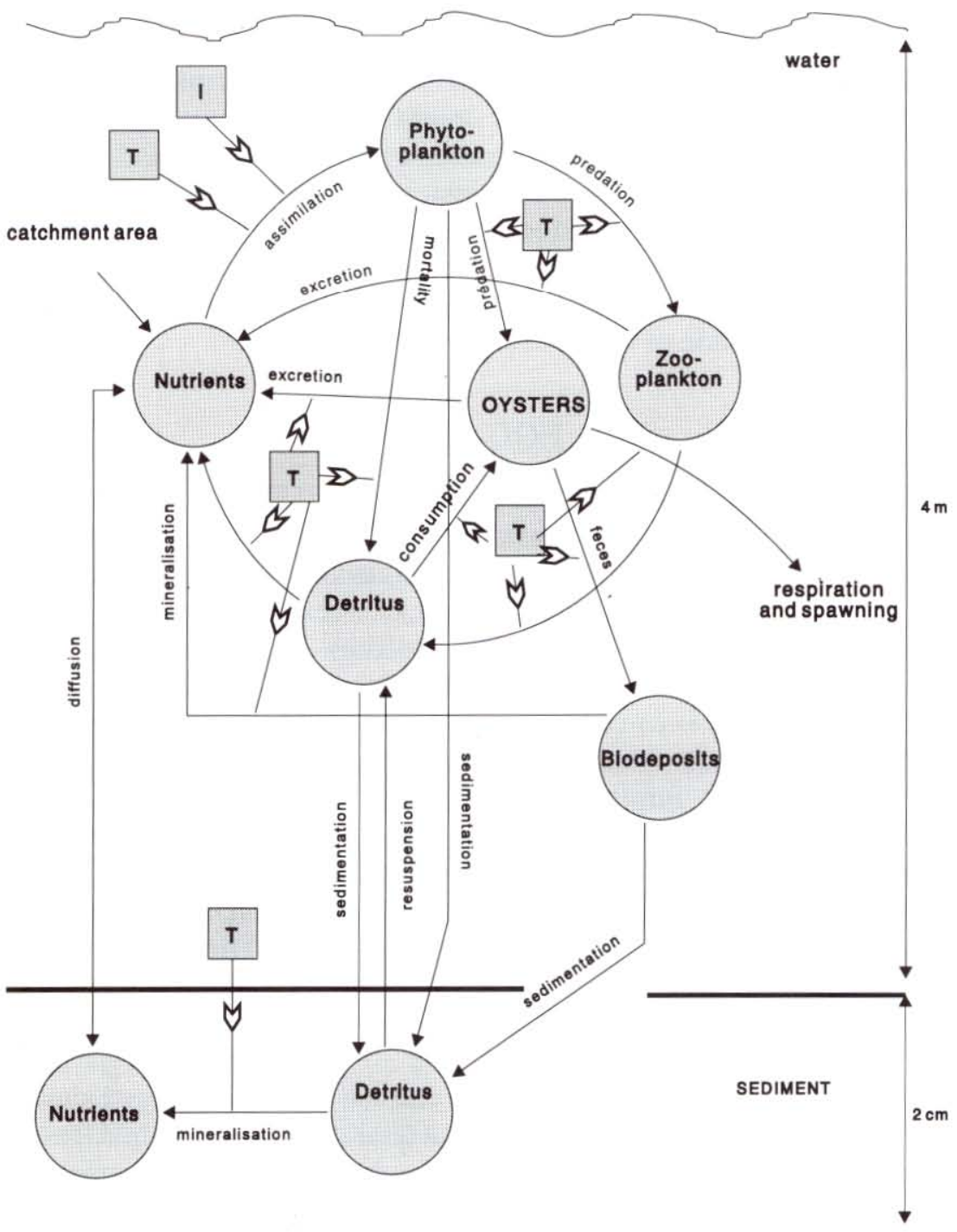

\section{variables}

T water temperature

I light irradiance

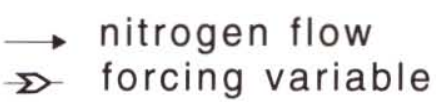

Fig. 2. Thau lagoon ecosystem model. The nitrogen flows $\left(\mathrm{gN} / \mathrm{m}^{3} / \mathrm{d}\right)$ were simulated during one year. The following variables (circles) considered: phytoplankton, oyster, zooplankton, detritus in the water column and the sediment, nutrients in the water and the sediment, biodeposits. 
These compartments corresponded to seven variables representing the temporal evolution of the concentrations (e.g., phytoplankton, zooplankton, dissolved inorganic nitrogen, and detritus in the water column), biomass (detritus in the sediment) or dry weight (oyster). The simplified ecosystem is represented in Fig. 2 . It could be considered similar to a mesocosm driven by nutrient input from the lagoon's watershed, temperature and light. Due to the previous assumptions, the standard simulation did not represent the real description of the system, but a summary of the most important flows expected. Therefore, one goal of this paper is to estimate parameters consistent with the observed seasonal fluctuations and the order of magnitude of the variables.

\section{EQUATIONS}

The oyster model was adapted from Raillard et al. (1993). It is based on computation of the filtration, ingestion, assimilation and respiration rates as functions of the body dry weight, temperature and food quantity. Oyster gill activity facilitates the seawater pumping, retaining particles over a few microns in diameter. Particles are ingested or rejected as pseudofeces. The ingestion efficiency depends on total particulate matter concentration. Below a value of $10 \mathrm{~g} / \mathrm{m}^{3}$ (dry weight), all the particles can be considered as ingested (ingestion efficiency equal to 1). In the Thau lagoon case, the model is simplified since this threshold is rarely reached. Little information is available for the assimilation efficiency. Powell et al. (1992) used a constant average value (0.75) obtained from measurements on Crassostrea virginica. The temperature effect on $C$. gigas was discussed by Raillard et al. (1993), who used the weight-temperature relationship developed by Bayne et al. (1976) for Mytilus edulis. The equation parameters representing the filtration and respiration rates were estimated from experimental results under various temperature and food conditions observed in the lagoon (Bougrier et al. in press) and ranging from $5-30^{\circ} \mathrm{C}$ and $0.01-0.06 \mathrm{~g} / \mathrm{N} / \mathrm{m}^{3} \mathrm{respec}-$ tively. Individual oyster growth was then derived from the energy balance calculated by the difference between energy input (assimilation) and output (respiration).

An attempt was made to consider the reproductive effort as described by Powell et al. (1992). They assumed that a part of the energy gained was used for reproduction and the remaining fraction for somatic growth. An empirical relationship between reproduction effort and temperature was derived to determine reproduction share in the oyster mass budget. When the total weight of reproductive products reached $20 \%$ of total dry weight, a spawning occurs. Similar formulations were used for $C$. gigas in the Thau lagoon case. Different temperature data sets relating reproductive effort and the spawning threshold were tested. Although more complex models have been developed (Ross \& Nisbet 1990; Van Haren \& Kooijman 1993), it is beyond the aim of this paper to develop a general formulation to assess reproduction effort. The energy budget was sufficiently 
robust to describe the overall oyster growth trend under some standard trophic conditions. The budget was calculated as an ordinary differential equation of the individual dry weight $W(\mathrm{~g})$ :

$$
\frac{d W}{d t}=(A-R) \cdot(1-R e)
$$

with $A$ representing assimilation rate, $R$ respiration rate, $R e$ reproduction efficiency. Formulation details of the assimilation rate are given in Appendix 1. Individual impact on the environment resulted from three processes: predation, biodeposition, and excretion of dissolved inorganic nitrogen. Predation is regarded as the particle retention (both phytoplankton and detritus), and biodeposition as the remaining food portion that is either ingested but not assimilated, or rejected as pseudofeces (Appendix 1). Only the dissolved inorganic nitrogen was regarded as an excretion product. However, it was not included in the energy budget since its energy value was negligible (Boucher-Rodoni \& Boucher 1990). The excretion equation was adapted from Outin (1990), who established a regression relationship between excretion rate $E x$ ( $\mathrm{gN} \mathrm{d} /$ individual), temperature $T$, and the individual dry weight $W$ :

$$
E x=\left(e_{1}+e_{2} \cdot T\right) \cdot W^{e_{3}}
$$

Primary production was influenced by temperature, nutrient concentration and light irradiance. An exponential function was chosen for the temperature effect (Chapelle 1991) and the nutrient limitation expressed with a Michaelis-Menten relationship. With regards to the light effect, the Steele equation was integrated over the water depth. Denoting $I_{z}$ the light irradiance at the depth $z$, the light attenuation was written:

$$
I_{z}=I_{0} \cdot e^{-k \cdot z}
$$

where $k$ is the light attenuation coefficient and $I_{0}$ the light irradiance at the water surface $\left(\mathrm{W} / \mathrm{m}^{2}\right)$. Using data from Hénard $(1978), k$ was estimated from vertical profiles of light availability at different locations. Since no relationship was established between the estimated $k$ values and environmental data (chlorophyll- $a$, turbidity - results not shown), $k$ was maintained constant during the simulations. Integrating the Steele equation:

$$
f\left(I_{z}\right)=\frac{I_{z}}{I_{o p t}} \cdot e^{\left(\begin{array}{cc}
1- & I_{z} \\
I_{\text {spt }}
\end{array}\right)}
$$


yielded a mean value of the light effect:

$$
\bar{f}=\frac{1}{H} \cdot \int_{z=0}^{H} f\left(I_{z}\right) d z=\frac{e}{k \cdot H} \cdot\left[e^{\left(\frac{-I_{H}}{I_{\text {opt }}}\right)}-e^{\left(\begin{array}{c}
\left(-I_{0}\right. \\
I_{\text {opt }}
\end{array}\right)}\right]
$$

where $I_{0}$ was the light irradiance at the water surface, and $I_{H}$ at the mean depth $H$. The phytoplankton growth rate was written:

$$
\frac{d P}{d t}=\mu_{\max } \cdot \bar{f} \cdot g(T) \cdot \frac{N_{\text {water }}}{k_{N}+N_{\text {water }}}
$$

$N_{\text {water }}$ representing the dissolved nitrogen concentration in the water (nutrients), and $g(T)$ a temperature function (see below). A natural mortality and a predation by zooplankton were subtracted from the previous equation. The mortality was a first order kinetics with a constant $m_{p}$ and was equal to: $m_{p} \cdot P \cdot g(T)$.

The zooplankton grazing on phytoplankton depend upon phytoplankton concentration $(P)$; it was expressed with an Ivlev-shape relationship with a threshold concentration $P_{\min }$ and multiplied by a temperature function $g(T)$ (Chapelle 1991):

$$
\frac{d Z}{d t}=p_{\max } \cdot g(T) \cdot\left(1-e^{-k_{z} \cdot \max \left(0, P-P_{\min }\right)}\right.
$$

As for the phytoplankton, a mortality rate was represented by a first order kinetics of the zooplankton $Z$ with a constant $m_{z}$. An excretion term was added (Chapelle 1991) as a first order kinetics characterized by the parameter $e_{Z}$. These two latter processes depended on the temperature and were multiplied by $g(T)$.

The temperature had a similar effect on most of the biological flows: mineralisation of detritus in sediment and seawater, primary production, phytoplankton mortality, grazing and excretion by the zooplankton. The function was an exponential with a coefficient $k_{T}$ equal to 0.07 , so that the nitrogen flow doubled when the temperature increased by $10^{\circ} \mathrm{C}$ :

$$
g(T)=e^{k_{T} \cdot T}
$$

All types of particulate matter except zooplankton were assumed to settle to the bottom. A sinking rate $k_{s}(\mathrm{~m} / \mathrm{d})$ was defined for phytoplankton, biodeposits, and detritus. The settling rate was simply defined by the product of the appropri- 
ate sinking rate and the concentration, which resulted in a vertical nitrogen flow $\left(\mathrm{gN} / \mathrm{m}^{3} / \mathrm{d}\right)$. For a variable $X$, the temporal variation due to the sedimentation was written:

$$
\frac{d X}{d t}=-k_{s}(X) \cdot X
$$

where $X$ could be $P$ (phytoplankton), $D$ (seawater detritus) or $B$ (biodeposits in the water). Another vertical flow was the diffusion from the sediment, empirically related to the difference between dissolved inorganic nitrogen concentration in water and sediment. The following contribution of the diffusion term to the nutrients budget in the water was obtained:

$$
\frac{d N_{\text {water }}}{d t}=\frac{k_{D} \cdot\left(N_{\text {sed }}-N_{\text {water }}\right)}{H_{w}}
$$

$k_{D}$ denoting the diffusion coefficient, and $H_{w}$ the water thickness. A similar quantity was then derived for nutrients contained in the sediment interstitial water $\left(N_{\text {sed }}\right)$ :

$$
\frac{d N_{\text {sed }}}{d t}=\frac{k_{D} \cdot\left(N_{\text {water }}-N_{\text {sed }}\right)}{H_{s}}
$$

$H_{s}$ denoting the sediment thickness. The last flow relating the water and the sediment was the detritus resuspension, expressed as a first order kinetics of the detritus in the sediment, with a constant $r$.

Two other functions were defined to compute the mineralisation of detritus in the water and in the sediment. The flows were written: $m w_{D} \cdot g(T) \cdot D$, and $m s_{D} \cdot g(T) \cdot D S$, with $m w_{D}$ and $m s_{D}$ denoting the mineralisation rate at $0{ }^{\circ} \mathrm{C}$ in the water and in the sediment respectively, and $D S$ the detritus in the sediment.

The list and values of all parameters are given in Tables 1 and 2 .

\section{CALIBRATION}

Most of the data were derived from the work by Hénard (1978), who conducted a survey of the phytoplankton, nitrate, nitrite concentrations, and the primary production at 20 stations spread all over the lagoon. These data provided enough information to calibrate several model parameters. The parameters were grouped into two sets. The first group dealt with parameters derived from direct measure- 
Table 1. List and values of the parameters used in the model, compared to some values found in the literature. Some values used in the model were obtained through calibration of simulation against observations. Others were chosen in the range of values used in other studies (see text).

\begin{tabular}{|c|c|c|c|}
\hline PARAMETER DEFINITION & UNIT & $\begin{array}{l}\text { MODEL } \\
\text { VALUE }\end{array}$ & $\begin{array}{l}\text { REFERENCE VALUES AND } \\
\text { SOURCES }\end{array}$ \\
\hline $\begin{array}{l}\text { Maximum growth rate of phytoplankton, } \\
\mu_{\max }\end{array}$ & $\mathrm{d}^{-1}$ & 0.9 & $\begin{array}{l}\text { 0.45 (Chapelle 1991) } \\
0.32-0.62 \text { (Jorgensen 1988) }\end{array}$ \\
\hline Temperature coefficient, $k_{T}$ & ${ }^{\circ} \mathrm{C}^{-1}$ & 0.07 & 0.07 (Chapelle 1991) \\
\hline Optimum light irradiance, $I_{o p t}$ & $\mathrm{~W} / \mathrm{m}^{2}$ & 80 & 80-120 (Chapelle 1991) \\
\hline Extinction coefficient, $k$ & $\mathrm{~m}^{-1}$ & 0.22 & \\
\hline $\begin{array}{l}\text { Michaelis-Menten constant for nitrogen, } \\
k_{\mathrm{N}}\end{array}$ & $\mathrm{gN} / \mathrm{m}^{3}$ & 0.028 & $\begin{array}{l}0.021 \text { (Chapelle 1991) } \\
0.028 \text { (Andersen \& Nival 1987) }\end{array}$ \\
\hline Phytoplankton mortality rate, $m_{P}$ & $\mathrm{~d}^{-1}$ & 0.1 & 0.03-0.1 (Andersen \& Nival 1987) \\
\hline Phytoplankton settling velocity, $k_{s}(P)$ & $\mathrm{m} / \mathrm{d}$ & 0.5 & $\begin{array}{l}0.7 \text { (Chapelle 1991) } \\
1.0 \text { (Passow 1991) } \\
\end{array}$ \\
\hline $\begin{array}{l}\text { Zooplankton maximum grazing rate at } \\
0^{\circ} \mathrm{C}, p_{\max }\end{array}$ & $\mathrm{d}^{-1}$ & 0.5 & 0.96-1.7 (Andersen \& Nival 1987) \\
\hline Ivlev constant, $k_{z}$ & $\mathrm{~m}^{3} / \mathrm{gN}$ & 10.4 & $\begin{array}{l}3.57 \text { (Chapelle 1991) } \\
\text { 23.6-28.6 (Andersen \& Nival 1987) }\end{array}$ \\
\hline $\begin{array}{l}\text { Threshold phytoplankton concentration, } \\
P_{\min }\end{array}$ & $\mathrm{gN} / \mathrm{m}^{3}$ & $1.410^{-4}$ & $1.410^{-4}-710^{-4}$ (Andersen \& Nival1987) \\
\hline Zooplankton mortality rate, $m_{\mathrm{z}}$ & $\mathrm{d}^{-1}$ & 0.04 & 0.024-0.06 (Andersen \& Nival 1987) \\
\hline Zooplankton excretion rate, $e_{z}$ & $\mathrm{~d}^{-1}$ & 0.063 & 0.067-0.086 (Andersen \& Nival 1987) \\
\hline $\begin{array}{l}\text { Mineralisation rate of detritus at } 0^{\circ} \mathrm{C} \text { in } \\
\text { water column, } m w_{\mathrm{D}}\end{array}$ & $\mathrm{d}^{-1}$ & 0.04 & 0.04 (Chapelle 1991) \\
\hline Settling velocity of detritus, $k_{s}(D)$ & $\mathrm{m} / \mathrm{d}$ & 1.5 & 1 (Chapelle 1991) \\
\hline$\underline{\text { Settling velocity of biodeposits, } k_{s}(B)}$ & $\mathrm{m} / \mathrm{d}$ & 100 & \\
\hline $\begin{array}{l}\text { Mineralisation rate at } 0^{\circ} \mathrm{C} \text { in sediment, } \\
m s_{\mathrm{B}}\end{array}$ & $\mathrm{d}^{-1}$ & $710^{-4}$ & $\begin{array}{l}0.004 \text { (Chapelle pers. comm.) } \\
10^{-4}-2.810^{-4} \text { (Kristensen \& Blackburn } \\
1987)\end{array}$ \\
\hline $\begin{array}{l}\text { Diffusion coefficient at water-sediment } \\
\text { interface, } k_{\mathrm{D}}\end{array}$ & $\mathrm{m}^{2} / \mathrm{d}$ & $10^{-3}$ & $810^{-3}$ (Chapelle 1993) \\
\hline Resuspension rate, $r$ & $\mathrm{~m}^{2} / \mathrm{d}$ & $3.210^{-4}$ & \\
\hline
\end{tabular}

ments or experiments. For example, the relationship between ecophysiological functions and environmental variables was based upon laboratory experiments. Conversion coefficients for watershed input (e.g., phytoplankton and zooplankton nitrogen content, oyster energy content) were assumed to be known with enough precision to consider that some standard variability would not change the model behavior. Similarly, the uncertainty of several factors was not considered. For instance, the temperature effect on some kinetics (e.g., mortality, primary production, mineralisation) was written in a standard exponential function. The second group of parameters did not influence the model results significantly. 
Table 2. Oyster model parameters (see Appendix 1 for the notations).

\begin{tabular}{|c|c|c|c|c|}
\hline FUNCTION & PARAMETER & UNIT & VALUE & REFERENCE \\
\hline \multirow{4}{*}{ Filtration } & $\begin{array}{l}\text { Optimum filtration rate for a } \\
\mathrm{g} \text { indivual (dry weight } \mathrm{f}_{1}\end{array}$ & $1 / \mathrm{hr} / \mathrm{g}$ & 4.825 & \multirow[t]{4}{*}{ Bougrier et al. in press } \\
\hline & $f_{2}$ & $1 / \mathrm{hr} / \mathrm{g}$ & 0.013 & \\
\hline & Optimum temperature $\mathrm{f}_{3}$ & ${ }^{\circ} \mathrm{C}$ & 18.954 & \\
\hline & Allometric coefficient $\mathrm{f}_{4}$ & & 0.439 & \\
\hline \multirow{4}{*}{ Respiration } & $\mathrm{r}_{1}$ & $\mathrm{mgO}_{2} / \mathrm{hr} / \mathrm{g}$ & 0.432 & Bougrier et al. in press \\
\hline & $r_{2}$ & $\mathrm{mgO}_{2} / \mathrm{hr} / \mathrm{g}$ & 0.613 & \\
\hline & r3 & & 1.042 & \\
\hline & Allometric coefficient $r_{4}$ & & 0.8 & \\
\hline \multirow{3}{*}{ Excretion } & Excretion rate at $0^{\circ} \mathrm{C} \mathrm{e}_{1}$ & $\begin{array}{l}\mathrm{gN} / \mathrm{d} / \mathrm{g} \\
\text { dry weight }\end{array}$ & 14.7 & \multirow[t]{3}{*}{ Outin 1990} \\
\hline & $\mathrm{e}_{2}$ & & 0.84 & \\
\hline & Allometric coefficient $e_{3}$ & & 0.7 & \\
\hline \multirow[t]{2}{*}{ Assimilation } & Temperature coefficient $a_{1}$ & & 0.015 & 0.033 (Raillard et al. 1993) \\
\hline & $a_{2}$ & & 0.033 & 0.033 (Raillard et al. 1993) \\
\hline \multirow{3}{*}{ Reproduction } & $\mathrm{re}_{1}$ & & 0.054 & $\begin{array}{l}\text { January to June: } 0.054 \\
\text { July to December: } 0.729 \\
\text { (Powell et al. 1992) }\end{array}$ \\
\hline & Temperature coefficient re ${ }_{2}$ & & 0.659 & $\begin{array}{l}\text { January to June: } 0.047 \\
\text { July to December: } 0.809 \\
\text { (Powell et al. 1992) }\end{array}$ \\
\hline & $\begin{array}{l}\text { Percentage of weight which } \\
\text { triggered the spawning }\end{array}$ & $\begin{array}{l}\% \text { of total } \\
\text { dry weight }\end{array}$ & 20 & 20 (Powell et al. 1992) \\
\hline \multirow{4}{*}{$\begin{array}{l}\text { Conversion } \\
\text { coefficient }\end{array}$} & Oxygen to energy $t_{O \rightarrow E}$ & $\mathrm{~J} / \mathrm{mgO}_{2}$ & 14.16 & \\
\hline & Energy to dry weight $t_{E \rightarrow W}$ & $\mathrm{~J} / \mathrm{g}$ & $1710^{3}$ & Outin 1990 \\
\hline & $\begin{array}{l}\text { Phytoplankton nitrogen to } \\
\text { energy } t_{N \rightarrow E}\end{array}$ & $\mathrm{~J} / \mathrm{gN}$ & $14210^{3}$ & Raillard et al. 1993 \\
\hline & Detritus nitrogen to energy & $\mathrm{J} / \mathrm{gN}$ & $18610^{3}$ & Grenz 1989 \\
\hline
\end{tabular}

These parameters concerned most of the primary production equations (e.g., Michaelis-Menten constant, optimum light, maximum growth rate, and phytoplankton mortality) and those of vertical exchanges (sinking velocities, diffusion between sediment and water). Simulations were sensitive to all these parameters. Time series of phytoplankton concentration, nutrients concentration and primary production (Hénard 1978) were used for tuning the previous parameters. The constraint that the sediment should remain stable prompted us to balance inflow (sedimentation) and outflow (resuspension, diffusion) on a yearly basis. This yielded a parameter range. When out of this range, simulated and observed val- 


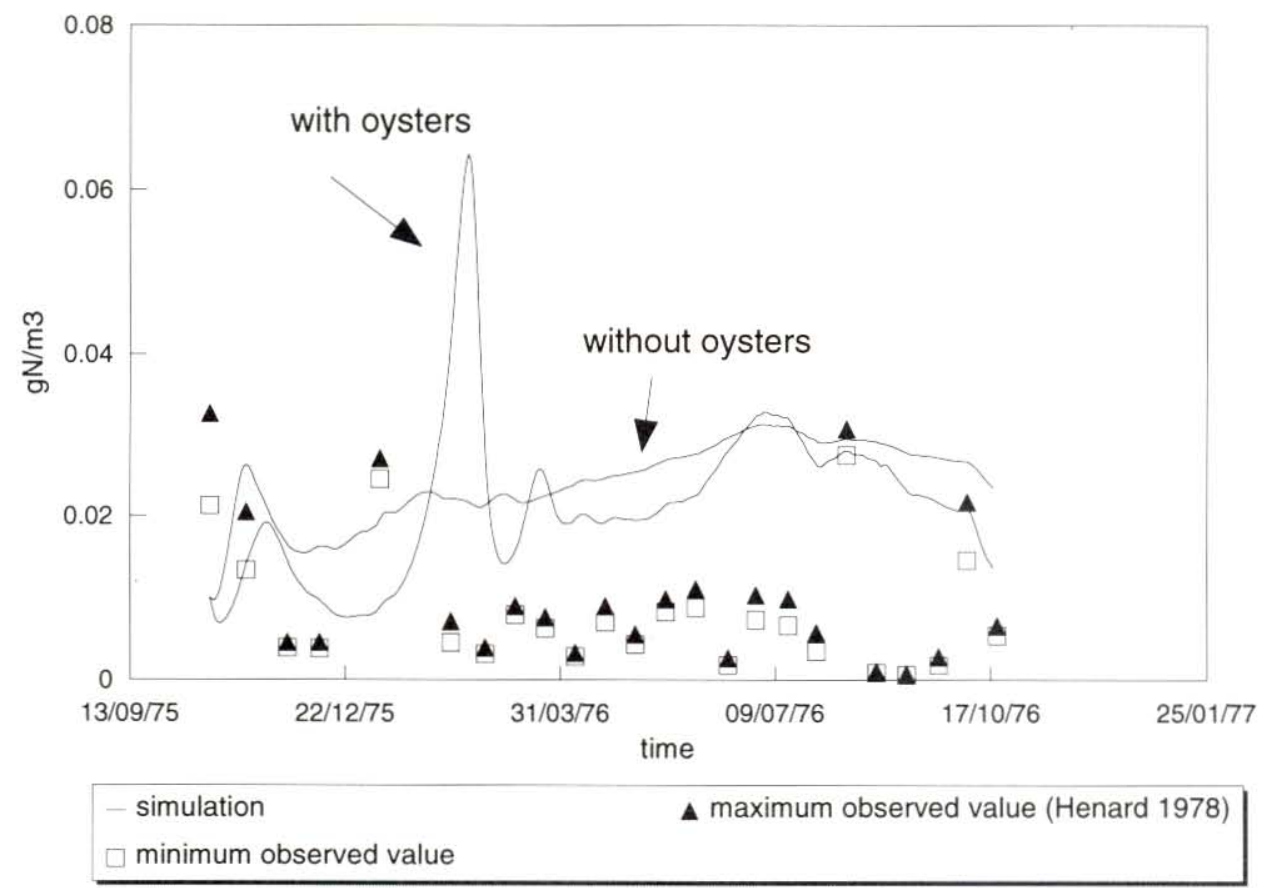

Fig. 3. Simulations and observed values of the phytoplankton $\left(\mathrm{gN} / \mathrm{m}^{3}\right)$. The range of the measurements made by Hénard (1978) is indicated. Two simulations were performed. The 'standard' referred to the simulation obtained after the calibration of the parameters. The 'modified' simulation was obtained once the oyster compartment and the nitrogen input from the catchment area were removed (see text).

ues were too different to validate the parameter values. Nevertheless, it must be kept in mind that simulations provided only qualitative estimates of the ecosystem behavior because of the strong assumptions introduced into the model.

The model was used in three different ways to assess the effect of filter-feeders on the nitrogen cycle. First, a global nitrogen budget was computed from the annual simulation. Comparing the average flows between compartments provided explanations for relationships between various compartments. Then, a sensitivity analysis for a varying oyster biomass was run to illustrate the changes in nitrogen concentration and flow due to this variability. Finally, a sensitivity analysis of the previously mentioned set of parameters was performed. The model was built with SENECA software (Hoop et al. 1992) in Fortran language and run on a PC computer. Although this study dealt with a single layer of sediment and a single layer in the water column, the definition of several horizontal layers in both water and sediment was implemented for further studies. 


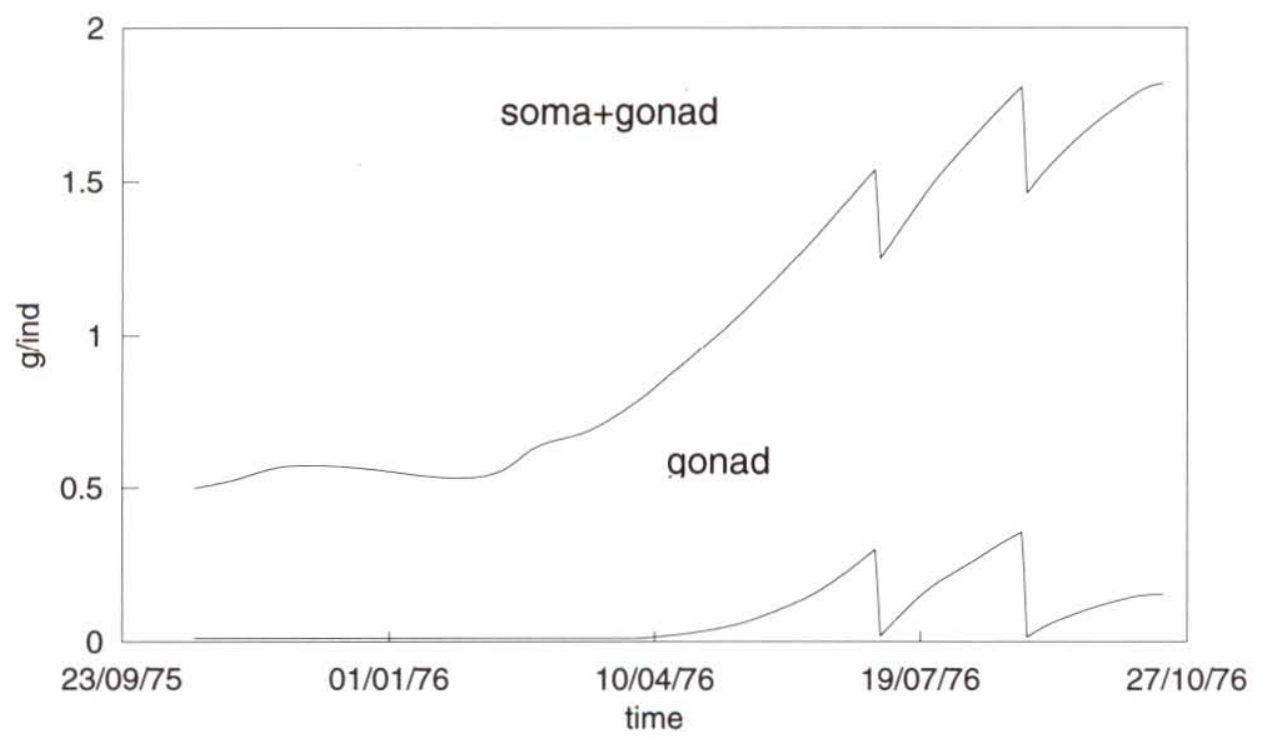

Fig. 4. Somatic and gonadic growth (g dry weight) of one oyster during one year. The total dry weight is the sum of the soma and the gonad weight.

\section{RESULTS}

The one-year simulation gave consistent results for the phytoplankton trend (Fig. 3). The phytoplankton varied from $0.01 \mathrm{gN} / \mathrm{m}^{3}$ in winter to 0.065 in early March. Two temporal patterns were observed. Oscillations in November and March corresponded to intensive blooms that disappeared quickly. In summer, a smooth increase reached a maximum in July $\left(0.03 \mathrm{gN} / \mathrm{m}^{3}\right)$, then declined until November. The simulation remained almost constantly above the observed values (by a factor of 2).

The low zooplankton value represented less than one thousandth of the phytoplankton nitrogen concentration. Based on the model runs, the zooplankton had no effect on the nitrogen dynamics. Actually, the zooplankton maximum grazing rate at $0^{\circ} \mathrm{C}$ must be reduced by $1.5 \mathrm{~d}^{-1}$ to avoid instabilities due to rapid oscillations between zoo- and phytoplankton (Chapelle 1991). Decreasing this parameter did not make it possible to regulate phytoplankton dynamics by zooplankton growth. In contrast, the oyster compartment affected the phytoplankton all year long, while oysters grew continuously from spring to autumn (Fig. 4). An individual oyster reached $1.8 \mathrm{~g}$ dry meat weight at the end of year 1 , reaching the marketable size. Two spawning events occurred in summer (July, September). 


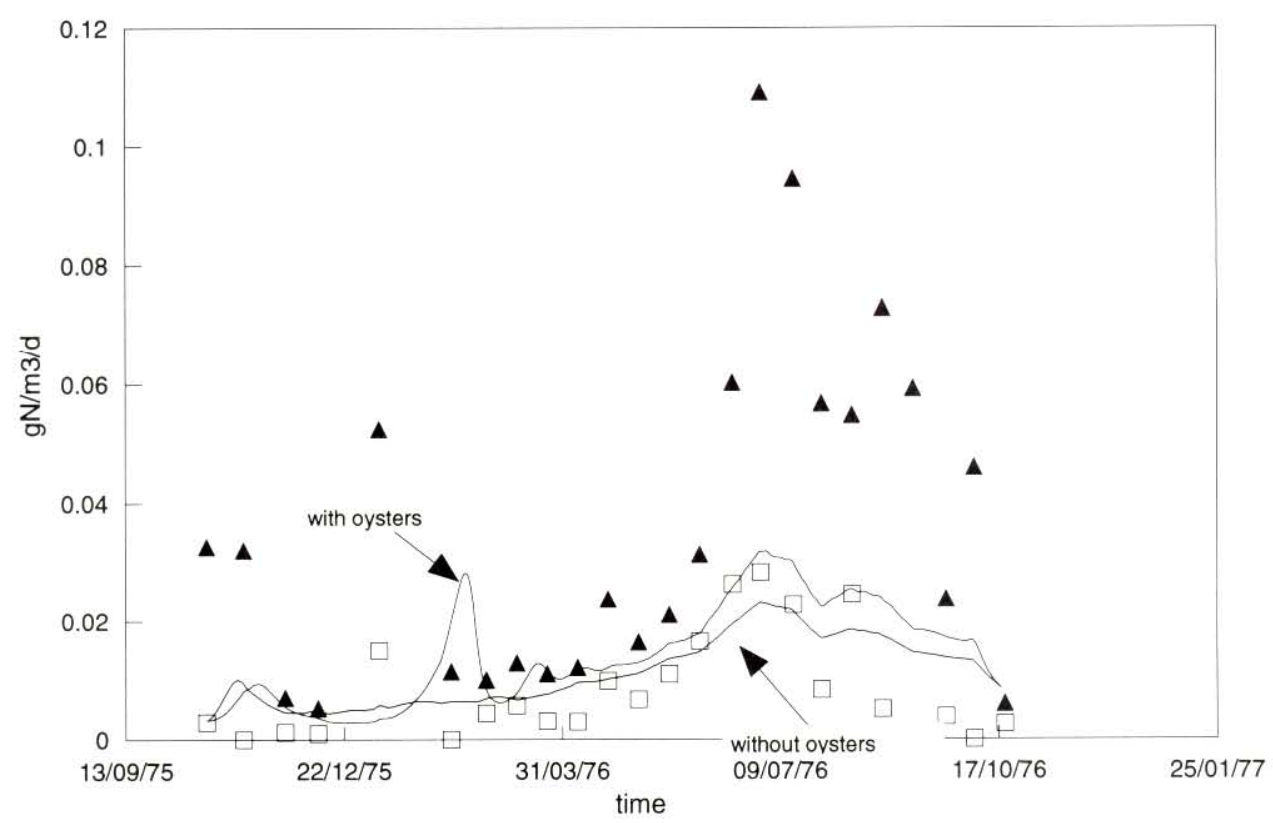

- simulation
$\square$ minimum observed value

Fig. 5. Same legend as for Fig. 3 for the primary production $\left(\mathrm{gN} / \mathrm{m}^{3} / \mathrm{d}\right)$. A 'standard' simulation (with oysters) and a 'modified' one (without oysters) were performed and compared to the data (Hénard 1978).

This agreed with the common observations for that species, which is characterized by a spawning period lasting over the summer.

The primary production (Fig. 5) showed a strong seasonal effect, similar to that reported by Hénard (1978). Although summer production was underestimated in the model, we were unable to increase this production substantially (e.g., by a factor of 2).

Increasing the phytoplankton maximum growth rate did not yield either higher phytoplankton concentration, or higher primary production, since both are regulated by the increased oyster grazing. In winter, the primary production remained at a low level (around $0.003 \mathrm{gN} / \mathrm{m}^{3} / \mathrm{d}$ ), constrained by both temperature (around $8^{\circ} \mathrm{C}$ ) and mainly light effects (Fig. 6). This resulted in an overestimated nitrogen increase in the water column. The phytoplankton bloom, occurring at the end of the winter, led to a sharp increase in primary production. Then, the production increased slowly in summer to reach $0.028 \mathrm{gN} / \mathrm{m}^{3} / \mathrm{d}$ in July.

The most unlikely results were related to the sharp increase in seawater nutri- 


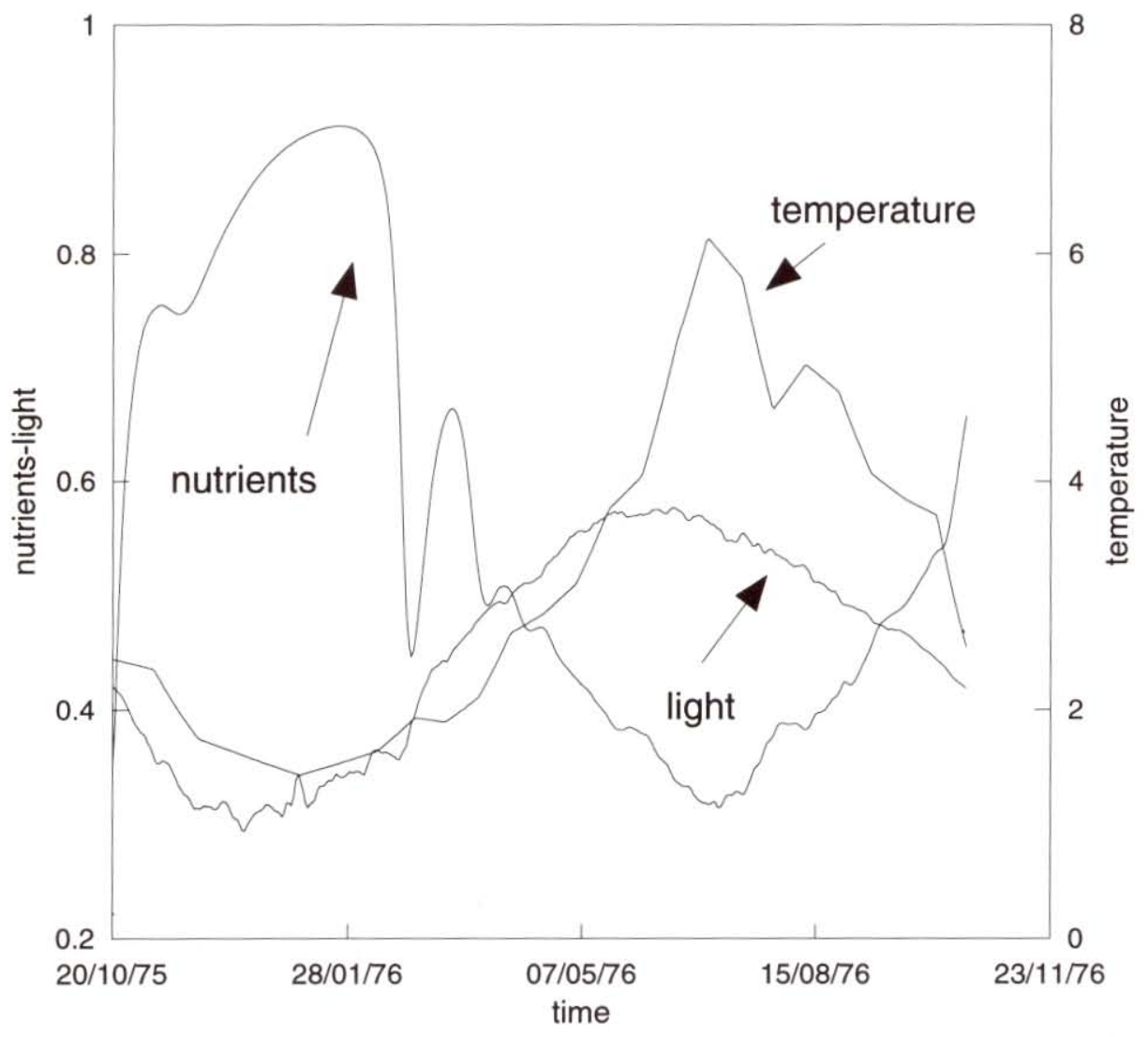

Fig. 6. Limiting effects (no units) taken into account for the mathematical formulation of the primary production. The temperature influenced the primary production through an exponential function; the light and nutrient effects varied between 0 and 1 by definition.

ents (Fig. 7), reaching $0.28 \mathrm{gN} / \mathrm{m}^{3}$ in February. Fig. 8 shows temporal trends of the main nutrient flows, resulting from primary production, watershed input, detritus mineralisation, oyster excretion and sediment release. All these flows except watershed input increased with temperature. In summer, the oysters' contribution to the nutrient budget was significant, though reduced compared to sediment release and mineralisation. In December and January, the low nutrient consumption by phytoplankton resulted in nutrient accumulation until the bloom in March. At that time, the phytoplankton increase reduced the nutrient concentration which remained below a $0.03 \mathrm{gN} / \mathrm{m}^{3}$ value until the end of the simulation. Except during winter, the simulated values were within the observation range. In summer, the rapid nutrient consumption by phytoplankton was compensated by 


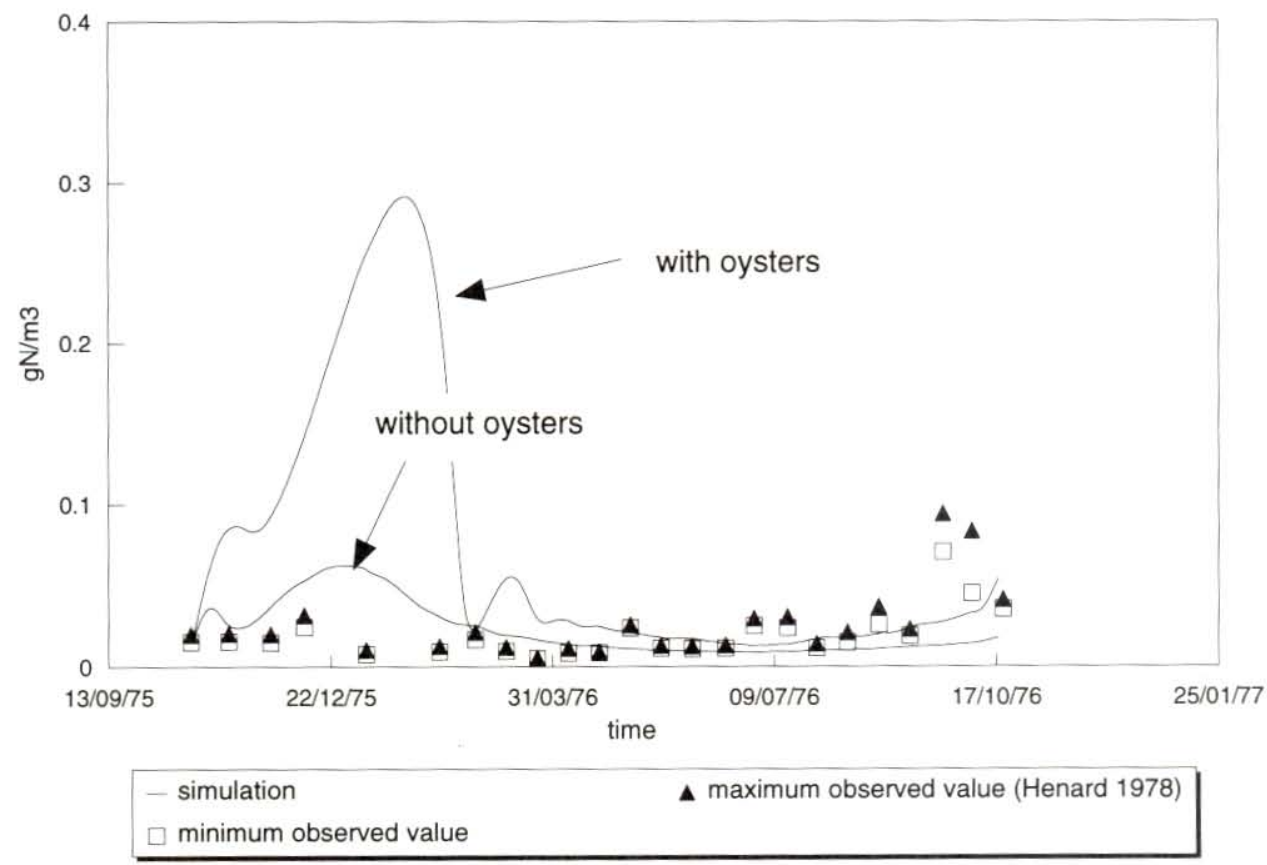

Fig. 7. Same legend as for Fig. 3 and 5. Here, the simulations and observed values of the dissolved inorganic nitrogen $\left(\mathrm{gN} / \mathrm{m}^{3}\right)$ are presented.

large nutrient flows due to mineralisation and sediment release. To a lesser extent, the oyster excretion contributed to balance the nutrient fluxes.

Since the total amount of nitrogen slightly increased during the simulation, the system was not fully conservative. This is mainly due to continuous watershed input. The only system output consisted in removing oyster biomass at the end of the year, simulating oyster harvesting by shellfish producers. Therefore, simulating the theoretical system behavior without the oyster population yielded a constant and important increase of total nitrogen concentration that precluded stability in the system. To compare nitrogen flows between simulations with and without oysters, the nitrogen input was suppressed in the latter case. This assumes that this input acted mainly on the yearly increase in total nitrogen. Modified simulations showed that the main difference resulted from reduced dissolved nitrogen accumulation in winter (Fig. 7), disappearance of the phytoplankton bloom in March (Fig. 3), and a lower primary production in summer (Fig. 5).

For standard simulation, a flow diagram was derived from averaged concentrations and flows (Fig. 9). Converted into nitrogen concentration, the oyster compartment had the largest average value $\left(0.11 \mathrm{gN} / \mathrm{m}^{3}\right)$. Then, nutrients $(0.072$ 


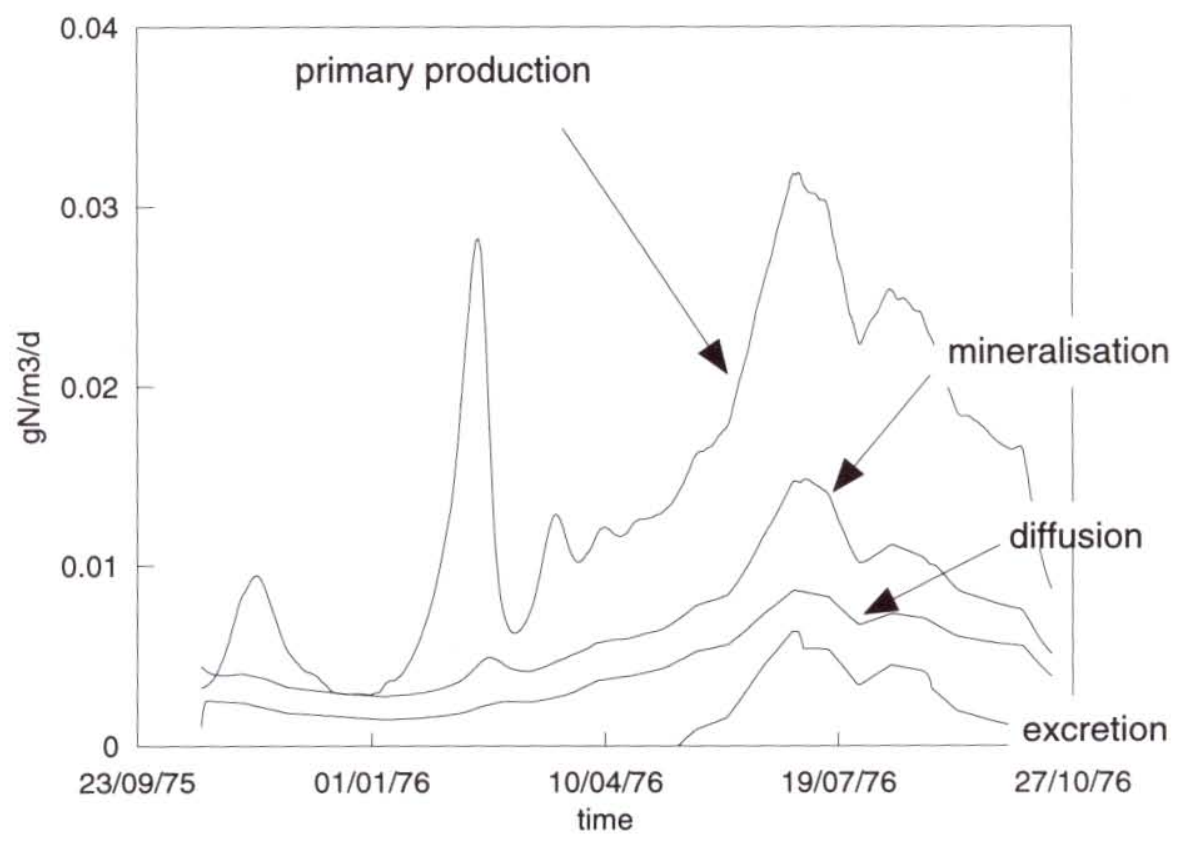

Fig. 8. The 'standard' simulation yielded the main dissolved inorganic nitrogen flows $\left(\mathrm{gN} / \mathrm{m}^{3} / \mathrm{d}\right)$ : the consumption by the phytoplankton through the primary production, the mineralisation of the detritus, the diffusion at the water-sediment interface, and the excretion by the oysters.

$\left.\mathrm{gN} / \mathrm{m}^{3}\right)$, detritus $(0.052)$, and phytoplankton $(0.022)$ were listed respectively. Biodeposits and zooplankton represented less than $510^{-4} \mathrm{gN} / \mathrm{m}^{3}$. However, the biodeposit compartment was significant. The reduced concentration resulted from a balance between oyster biodeposition and sedimentation rates, driven by a large sinking velocity coefficient (Table 1 ). With regard to zooplankton, low flow values showed the limited contribution to the nitrogen cycle. Grazing, excretion, and mortality rates were low (factor of $10^{-3}$ ) compared to other system flows. Largest flows concerned sedimentation and resuspension rates (19.7 and $29.510^{-3} \mathrm{gN} / \mathrm{m}^{3} / \mathrm{d}$, respectively), primary production $\left(1510^{-3} \mathrm{gN} / \mathrm{m}^{3} / \mathrm{d}\right)$, and consumption of detritus by oysters $\left(1310^{-3} \mathrm{gN} / \mathrm{m}^{3} / \mathrm{d}\right)$. Moreover, detritus mineralisation $\left(6.710^{-3}\right)$, grazing on phytoplankton by oysters $\left(4.010^{-3}\right)$, and release of dissolved nitrogen from the sediment $\left(4.210^{-3}\right)$ were also high.

Further information was provided by computing sensitivity coefficients derived from calculations of the sum of squared differences between nominal simulation and simulations using new parameter values. This procedure was applied to the parameters listed in Table 3. The sensitivity coefficients were computed for the main variables: phytoplankton, nutrients, detritus and dry meat weight of 


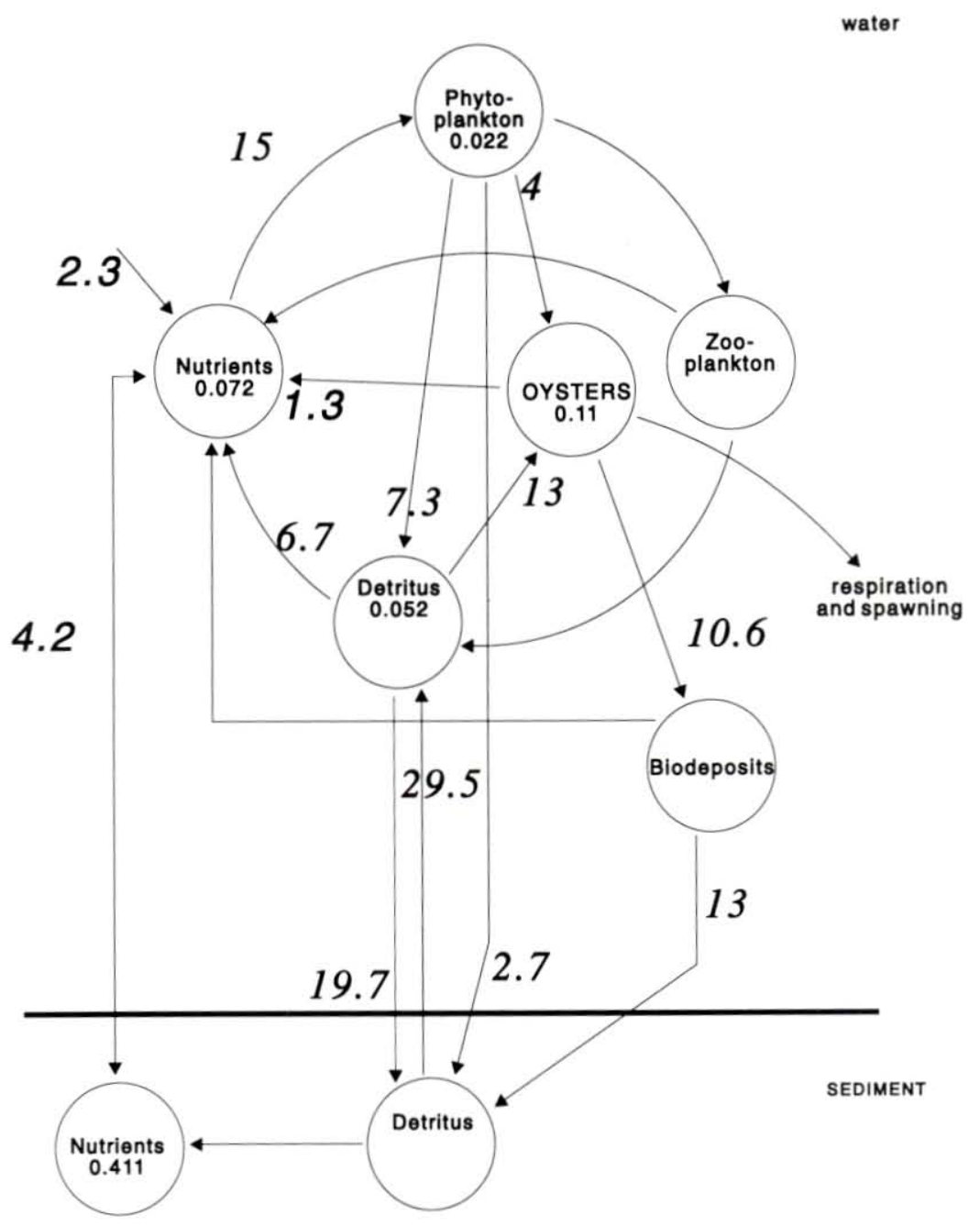

Fig. 9. The nitrogen flows $\left(10^{-3} \mathrm{gN} / \mathrm{m}^{3} / \mathrm{d}\right)$ yielded by the 'standard' simulation were averaged to compare the paths on the annual basis. The flows involving the zooplankton were negligible and not shown on the graph. Concentrations $\left(\mathrm{gN} / \mathrm{m}^{3}\right)$ were indicated within the circles. Multiplying the flows by the mean depth $(4 \mathrm{~m})$ converts the units in $\mathrm{gN} / \mathrm{m}^{2} / \mathrm{d}$.

oysters (Table 3 ). The largest sensitivity coefficients were related to maximum phytoplankton growth rate. Obviously, this parameter is critical for phytoplankton and nutrient concentrations, affecting also oyster weight. Other parameters such as detritus resuspension and sedimentation rates affected this variable. This effect was related to contribution of detritus to the oyster diet. The largest sensitivity coefficients concerned the nutrients compartment (in the water), which was 
Table 3. Sensitivity coefficients of the model variables to $10 \%$ change of some parameters. The coefficients were standardized to enable comparisons between the variables. The highest coefficients are written with bold to highlight the processes which were very sensitive to a change of the parameters.

\begin{tabular}{l|c|c|c|c|c}
\hline Parameter\Variable & $\begin{array}{c}\text { Phytoplank- } \\
\text { ton }\end{array}$ & $\begin{array}{c}\text { Nutrients in } \\
\text { water }\end{array}$ & Detritus & $\begin{array}{c}\text { Nutrients in } \\
\text { sediment }\end{array}$ & Oysters \\
\hline $\begin{array}{l}\text { Phytoplankton } \\
\text { mortality }\end{array}$ & $\mathbf{0 . 1 2 6}$ & $\mathbf{0 . 1 6 9}$ & 0.020 & 0.041 & 0.011 \\
\hline $\begin{array}{l}\text { Maximum growth } \\
\text { rate of phytoplankton }\end{array}$ & $\mathbf{0 . 3 1 3}$ & $\mathbf{0 . 6 3 4}$ & $\mathbf{0 . 0 4 6}$ & $\mathbf{0 . 1 3 5}$ & $\mathbf{0 . 0 2 5}$ \\
\hline $\begin{array}{l}\text { Michaelis-Menten } \\
\text { constant }\end{array}$ & 0.027 & 0.095 & 0.005 & 0.015 & 0.005 \\
\hline $\begin{array}{l}\text { Optimum light } \\
\text { irradiance }\end{array}$ & 0.099 & $\mathbf{0 . 1 5 0}$ & 0.016 & 0.042 & 0.007 \\
\hline $\begin{array}{l}\text { Settling velocity of } \\
\text { phytoplankton }\end{array}$ & 0.093 & 0.105 & 0.014 & 0.031 & 0.014 \\
$\begin{array}{l}\text { Settling velocity of } \\
\text { detritus }\end{array}$ & 0.015 & 0.024 & $\mathbf{0 . 0 4 8}$ & 0.007 & 0.053 \\
\hline $\begin{array}{l}\text { Resuspension rate } \\
\text { Diffusion coefficient }\end{array}$ & 0.023 & 0.034 & $\mathbf{0 . 0 7 0}$ & 0.010 & 0.077 \\
\hline
\end{tabular}

sensitive to phytoplankton mortality, growth rates, and optimum light irradiance. By comparison, the Michaelis-Menten constant, included into the nitrogen limiting function used to compute phytoplankton growth rate, had limited effect.

\section{DISCUSSION}

Annual simulated flows and biomass were consistent with observations. A literature review shows that biodeposition was about 440 tons N/ yr for the whole lagoon (Grenz 1989; Péna 1989; Deslous-Paoli (unpub.)). Based on a $26510^{6} \mathrm{~m}^{3}$ lagoon volume, our computation yielded a value of 1,250 tons $\mathrm{N} / \mathrm{yr}$. Although likely overestimated, the above-mentioned authors reported a 6,600 tons N/yr sedimentation rate. The same flux calculated by the model reached 1,900 tons N/ yr. Other valuable insight concerned the sediment diffusion $(1,250$ tons $\mathrm{N} / \mathrm{yr})$, oyster excretion ( 220 tons $\mathrm{N} / \mathrm{yr}$ ) and oyster consumption of organic matter ( 800 tons $\mathrm{N} / \mathrm{yr}$ ). Similar flows estimated by using the model were 400,126 , and 1,644 tons N/yr, respectively. Since they are usually derived from local and individual measurements, yearly estimates from available data are roughly estimates of the global fluxes occurring within the ecosystem. However, the model was based upon strong assumptions (e.g., oyster stock management, single primary-level species, no trophic competitor, smoothing high frequency meteoro- 
logical disturbances) and was therefore sensitive to parameters used for mathematical formulation of the primary production. Thus, the present model should be considered as a qualitative way to investigate dynamics among several dominant compartments.

The model provided a dynamic view of a simplified ecosystem behavior, where vertical exchanges between sediment and water (e.g., nutrient diffusion, sedimentation and resuspension), primary production and grazing by a filter-feeder population were considered. The model showed a distinct seasonal effect resulting from temperature and light irradiance, the two main forcing functions characterized by a seasonal trend. Temperature affected most of the biological flows (primary production, grazing, recycling of detritus). Moreover, light was the main factor limiting primary production in winter, when the nutrient compartment was characterized by a strong increase. Besides seasonal trends, specific events occurred combining nutrients and phytoplankton interactions, and predation by the oyster population. The model described rapid and short term phytoplankton bloom, sensitive to the parameter values used to compute primary production kinetics. This bloom was followed by a significant increase in oyster biomass, since oysters fed on phytoplankton. A significant impact of the oyster population resulted in trapping a large amount of nitrogen, then partly recycling it by biodeposition and excretion. The comparison between the two simulations with and without the oyster compartment confirmed the importance of this compartment as a nitrogen well. In the latter case, yearly ecosystem stability can only be reached by impeding watershed nitrogen input. This prompts us to question the stability of a closed system driven by an external nitrogen input. Herman (1993) concluded that suspension feeders can stabilize open ecosystems, e. g., systems crossed by a nitrogen flow. These flows can be induced by hydrodynamics or biological processes such as burial in the sediment and denitrification. The hydrodynamics could be significant in bays and estuaries, where residence time of particulate or dissolved matter is reduced by physical transport (Bacher 1993). The residence time was also presented as a parameter characteristic of ecosystems, governing several features of interspecific competitions (Officer et al. 1982; Hily 1991). Without such a throughflow, nitrogen accumulation within the system yielded unstable behavior resulting from fast kinetics linking nutrients to phytoplankton, and phytoplankton to zooplankton. Other simulations without oysters and with nitrogen input may illustrate the pattern that, over a given threshold of total nitrogen in the system, fast oscillations occur. In a simplified ecosystem model, the oyster compartment played an important role as a nitrogen well and stabilizing factor. The zooplankton had a minor effect on the nitrogen cycle, and its biomass was so reduced that the secondary trophic level was dominated by filter-feeders. As regards the stability problem, another comment can be made on disturbances created by meteorological conditions. Millet \& Cecchi (1992) showed that the wind had an effect on the phytoplankton biomass. They argued that 
phytoplankton dynamics may be influenced by water turbulence. Carper \& Bachmann (1984) showed that the wind had a major effect on shallow water turbidity, which can be related to statistical characteristics of wind intensity and direction. This provides clues to include random events of resuspension of detritus from the sediment into the water, where high frequencies of detritus and living matter can be observed. Based on this hypothesis, we might question if the model incorporating random events to reflect the overall ecosystem behavior should be modified or whether the stability should be preserved. This emphasizes the need for further research on the effect of filter-feeders on the ecosystem. The stability has been addressed by several authors, as well as the competition between zooplankton and filter-feeders (Officer et al. 1982), and resilience and vulnerability concepts (Herman \& Scholten 1990). These characteristics could not be addressed using our simplified model. However, the structural shifts in ecosystems yielded by species introduction should be considered. Ecosystems are naturally unstable and may have original responses to external disturbances, not necessarily considered by the present model. For example, phytoplankton may escape grazing by filter-feeders. Barillé et al. (1993) demonstrated that the retention efficiency depends on particle size and that the maximum retention efficiency is found over a specific size range of several microns. Therefore, oyster filtration has no effect on picoplankton, so that picoplankton blooms and zooplankton grazing should occur even under a large predation pressure from oysters. To address this issue, in situ measurements of primary production and phytoplankton abundance in the near vicinity of cultivated filter-feeders should be compared using similar parameters in natural seawater.

\section{CONCLUSION}

A simple model of the nitrogen flows in the Thau lagoon demonstrated the strong effect of the impact of filter-feeders through the consumption of phytoplankton and detritus and through biodeposition. These processes affected the nitrogen cycle in several ways. Biodeposition increased the amount of detritus in the sediment, so that the water-sediment interface played a critical role in nitrogen regeneration. Secondly, the predation of filter-feeders on the phytoplankton overwhelmed the zooplankton predation and maintained the phytoplankton concentration at low values. Also, the phytoplankton growth rate was high and resulted in an ability to use the available dissolved inorganic nitrogen when no light limitation of the primary production occurred. Last of all, the model stressed the importance of the detritus compartment as a source of organic matter particles for the filter-feeder compartment.

These results illustrate several topics addressed by an inter-disciplinary pro- 
gram on the biological flows in the Thau lagoon (Deslous-Paoli et al. 1993). New data have been collected in cultivated oyster areas and outside these areas to assess differences resulting from filter-feeding activity. These discrepancies are enhanced by low current velocities (Millet 1989) leading to slow seawater mixing. Preliminary results of in situ measurements confirmed that nitrogen cycling varies between areas. Another point is related to the sediment contribution to the nitrogen cycle. Chapelle (1993) modelled the phosphorus, nitrogen and oxygen dynamics within the sediment to determine relationships between oxygen demand, mineralisation of detritus and ammonium nitrification. This is a preliminary step to model the anoxic events usually observed in summer (Deslous-Paoli et al. 1993). Coupling the latter and the present models, with regards to spatial variability due to the cultivated areas, will be the next development of this ecosystem modelling.

Acknowledgements. The authors wish to thank P. Goulletquer and anonymous reviewers for their help in improving the manuscript

APPENDIX 1. The oyster ecophysiology model.

Two variables were used to describe the oyster: the dry meat weight $W$ and the gonadic weight $S$. The energy budget equation included the following physiological functions:

i) filtration rate ( $1 / \mathrm{hr}$ individual) $F$ represents the water volume one oyster is able to filter. Filtration rate is a function of temperature $T$ and individual dry weight $W$ :

$$
F=\left(f_{1}+f_{2} \cdot\left[T-f_{3}\right]^{2}\right) \cdot W^{f_{4}}
$$

Derived from experiments (Bougrier et al. in press), this relationship shows a maximum effect of the temperature for $T=f_{3}\left(\right.$ since $\left.\mathrm{f}_{2}<0\right)$.

ii) ingestion rate $I$ is the quantity of organic matter in the water entering the animal gut per time unit:

$$
I=F \cdot X
$$

under the assumption of no rejection, with $\mathrm{X}$ denoting food concentration (phytoplankton, detritus).

iii) assimilation rate $A$ estimates the amount of the gained organic matter converted to energy for animal growth, reproduction and metabolism. Assuming 
a linear relationship with temperature (Bayne et al. 1976), it could be written:

$$
A=I \cdot\left(a_{1} \cdot T+a_{2}\right) \cdot t_{N \rightarrow E}
$$

The coefficient $t_{N \rightarrow E}$ is added to convert the food quantity ( $\mathrm{gN}$ ) to energy (J). The difference between the ingestion and assimilation rates equals the biodeposition.

iv) the counterpart of the energy gained through the food consumption is the respiration rate $R$ :

$$
R=\left(r_{1}+r_{2} \cdot r_{3}^{T}\right) \cdot W^{r_{4}} \cdot t_{O \rightarrow E}
$$

which is also derived from experiments and depends upon the temperature and the animal dry weight (Bougrier et al. in press). In that case, the temperature effect is exponential and consequently, exhibited no maximum. The respiration is initially expressed as an oxygen consumption $\left(\mathrm{mgO}_{2} / \mathrm{hr} /\right.$ individual), and converted to energy through the multiplication by the $t_{O \rightarrow E}$ factor.

v) using the formulation given by Powell et al. (1992), energy devoted to reproduction is a fraction $R e$ of the total energy budget, with $R e$ linearly depending on the temperature:

$$
R e=r e_{1}+r e_{2} \cdot T
$$

vi) therefore, the differential equations governing animal dry weight (converted to energy) $E_{W}$ and gonad $E_{G}$ are:

$$
\begin{gathered}
\frac{d E_{W}}{d t}=(A-R) \cdot(1-R e) \\
\frac{d E_{G}}{d t}=(A-R) \cdot R e
\end{gathered}
$$

The dry weight could be obtained through energy transformation to mass using the coefficient: $t_{E \rightarrow W}$

$$
W=E_{W} \cdot t_{E \rightarrow W}
$$




\section{REFERENCES}

Andersen, V. \& P. Nival, 1987. Modelling of planktonic ecosystem in an enclosed water column. - J. Mar. Biol. Ass. 67: 407-430.

Bacher, C., 1993. Ecosystem modelling: sensitivity of physical characteristics to spatial box design. - In R. F. Dame (ed.): Bivalve Filter-feeders in Estuarine and Coastal Ecosystem Processes. NATO ASI Series Volume 33: 517-518. Springer-Verlag, Berlin, Heidelberg.

Barillé, L., J. Prou, M. Héral \& S. Bougrier, 1993. No influence of food quality but rationdependent retention efficiencies in the Japanese oyster Crassostrea gigas. - J. Exp. Mar. Biol. Ecol. 171: 91-106.

Bayne, B. L., J. Widdows \& R. J. Thompson, 1976. Physiological integrations. - In B. L. Bayne (ed.): Marine mussels: their ecology and physiology. IBP 10: 261-291. Cambridge University Press.

Boucher-Rodoni, R. \& G. Boucher, 1990. In situ study of the effect of oyster biomass on benthic metabolic exchange rates. - Hydrobiologia 206: 115-123.

Bougis, P., 1974. Ecologie du plancton marin. II. Le zooplancton. Masson et Cie, Paris, 200 pp.

Bougrier, S., P. Geairon, J. M. Deslous-Paoli, C. Bacher \& G. Jonquières, 1995. Allometric relationships and effects of temperature on clearance and oxygen consumption rates of Crassostrea gigas (Thunberg). - Aquaculture, in press.

Carper, G. L. \& R. W. Bachmann, 1984. Wind resuspension of sediments in a prairie lake. - Can. J. Fish. Aquat. Sci. 41: 1763-1767.

Chapelle, A., 1991. Modélisation d'un écosystème marin côtier soumis à l'eutrophisation: la baie de Vilaine (Sud-Bretagne). Etude du phytoplancton et du bilan en oxygène. - Thèse Univ. Paris VI, $201 \mathrm{pp}$.

Dame, R. F., 1993. The role of bivalve filter-feeder material fluxes in estuarine ecosystems. - In R.F. Dame (ed.): Bivalve Filter-feeders in Estuarine and Coastal Ecosystem Processes. NATO ASI Series Volume 33: 245-270. Springer-Verlag, Berlin, Heidelberg.

Deslous-Paoli, J.-M., A.-M. Lannou, P. Geairon, S. Bougrier, O. Raillard \& M. Héral, 1992. Effects of the feeding behaviour of Crassostrea gigas (Bivalve Molluscs) on biosedimentation of natural particulate matter. - Hydrobiologia 231: 85-91.

Deslous-Paoli, J.-M., N. Mazouni, P. Souchu, S. Landrein, P. Pichot \& C. Juge, 1993. Oyster farming impact on the environment of a mediterranean lagoon (Thau) (Preliminary results of the OXYTHAU programme). - In R. F. Dame (ed.): Bivalve Filter-feeders in Estuarine and Coastal Ecosystem Processes. NATO ASI Series Volume 33: 519-520. Springer-Verlag, Berlin, Heidelberg.

Gasc, A., 1993. Les apports du bassin versant: implication dans l'aquaculture des lagunes méditerranéennes françaises. - Rapp. D.E.A. Univ. Aix-Marseille, 17 pp.

Grenz, C., 1989. Quantification et destinée de la biodéposition en zones de production conchylicole intensive en Méditerranée. - Thèse Univ. Aix-Marseille 2, 145 pp.

Hamon, P. Y. \& H. Tournier, 1990. Etude des stocks de mollusques élevés dans l'étang de Thau de 1981 à 1987. - Rapport Ifremer Sète.

Hénard, D., 1978. Production primaire d'une lagune méditerranéenne. Etang de Thau (Hérault) Année 1976. - Thèse Univ. Sciences et Techniques du Languedoc, Montpellier, 85 pp.

Héral, M., 1993. Why carrying capacity models are useful tools for management of bivalve molluscs culture. - In R.F. Dame (ed.): Bivalve Filter-feeders in Estuarine and Coastal Ecosystem Processes. NATO ASI Series Volume 33: 455-478. Springer-Verlag, Berlin, Heidelberg. 
Héral, M., D. Razet, J.-M. Deslous-Paoli, J.-P. Berthomé \& J. Garnier, 1983. Caractéristiques saisonnières de l'hydrobiologie du complexe estuarien de Marenne-Oléron (France). - Rev. Trav. Inst. Pêches marit. 46(2): 97-119.

Herman, P. M. \& H. Scholten, 1990. Can suspension-feeders stabilise estuarine ecosystems. - In M. Barnes \& R. N. Gibson (eds): Trophic Relationships in the Marine Environement. Proc. 24th Europ. Mar. Biol. Symp.: 104-116. Aberdeen University Press.

Herman, P. M., 1993. A set of models to investigate the role of benthic suspension feeders in estuarine ecosystems. - In R.F. Dame (ed.): Bivalve Filter-feeders in Estuarine and Coastal Ecosystem Processes. NATO ASI Series Volume 33: 421-454. Springer-Verlag, Berlin, Heidelberg.

Hily, C., 1991. Is the activity of benthic suspension feeders a factor controlling water quality in the Bay of Brest?. - Mar. Ecol. Prog. Ser. 69: 179-188.

Hoop, B. J. de, P. M. J. Herman, H. Scholten \& K. Soetaert, 1992. SENECA 1.5. A simulation environment for ecological applications. User Manual. - Netherlands Institute of Ecology, Centre for Estuarine and Coastal Ecology, Yerseke.

Jarry, V., M. Fiala, G.-F. Frisoni, G. Jacques, J. Neveux \& M. Panouse, 1990. The spatial distribution of phytoplankton in a Mediterranean lagoon (Etang de Thau). - Oceanologica Acta 13(4): 503-512.

Jorgensen, S. E., 1988. Fundamentals of ecological modelling. - Developments in environmental modelling 9. Elsevier, Amsterdam, $391 \mathrm{pp}$.

Jouffre, D., T. Lam-Hoai, B. Millet \& M. Amanieu, 1991. Structuration spatiale des peuplements zooplanctoniques et fonctionnement hydrodynamique en mileu lagunaire. - Oceanologica Acta 14(5): 489-504

Kristensen, E. \& T. H. Blackburn, 1987. The fate of organic carbon and nitrogen in experimental marine sediment systems: influence of bioturbation and anoxia. - J. Mar. Res. 45: 231-257.

Lam-Hoai, T. \& M. Amanieu, 1989. Structures spatiales et évolution saisonnière du zooplancton superficiel dans deux écosystèmes lagunaires nord-méditerranéens. - Oceanologica Acta 12(1): 65-77.

Legendre, P., M. Trousselier, V. Jarry \& M.-J. Fortin, 1989. Design for simultaneous sampling of ecological variables: from concepts to numerical solutions. - Oikos 55: 30-42.

Millet, B., 1989. Fonctionnement hydrodynamique du bassin de Thau. Validation écologique d'un modèle numérique de circulation (programme Ecothau). - Oceanologica Acta 12(1): 37-46.

Millet, B. \& P. Cecchi, 1992. Wind-induced hydrodynamic control of the phytoplankton biomass in a lagoon ecosystem. - Limnol. Oceanogr. 37(1): 140-146.

Officer, C. B., T. J. Smayda \& R. Mann, 1982. Benthic filter feeding: a natural eutrophication control. - Mar. Ecol. Prog. Ser. 9: 203-210.

Outin, V., 1990. Ecophysiologie de l'huitre Crassostrea gigas (Thunberg) en milieu naturel. Thèse Univ. Paris VI, 130 pp.

Passow, U., 1991. Species-specific sedimentation and sinking velocities of diatoms. - Marine Biology 108: 449-455.

Péna, G., 1989. Sels nutritifs et micropolluants métalliques dans un écosystème lagunaire: l'étang de Thau. - Thèse Univ. Sciences et Techniques du Languedoc, 143 pp.

Picot, B., G. Péna, C. Casellas, D. Bondon \& J. Bontoux, 1990. Interpretation of the seasonal variations of nutrients in a mediterranean lagoon: étang de Thau. - Hydrobiologia 207: 105-114.

Powell, E. N., E. E. Hofmann, J. M. Klinck \& S. M. Ray, 1992. Modeling oyster populations. I. A commentary on filtration rate. Is faster always better? - J. Shellfish Res 11(2): 387-398.

Raillard, O., J.-M. Deslous-Paoli, M. Héral \& D. Razet, 1993. Modélisation du comportement nutritionnel et de la croissance de l'huitre japonaise Crassostrea gigas. - Oceanologica Acta 16(1): 73-82. 
Ross, A. H. \& R. M. Nisbet, 1990. Dynamic models of growth and reproduction of the mussel Mytilus edulis. - Funct. Ecol. 4: 777-787.

Van Haren, R. J. F. \& S. A. L. M. Kooijman, 1993. Application of a dynamic energy budget model to Mytilus edulis (L.). - Neth. J. Sea Res. 14: 349-361.

Vaulot, D. \& G. F. Frisoni, 1986. Phytoplanktonic productivity and nutrients in five mediteranean lagoons. - Oceanologica Acta 9(1): 57-63.0 